\title{
HAMBATAN DAN FAKTOR PENYEBABNYA PRAKERIN DITINJAU DARI PERSIAPAN, PELAKSANAAN, DAN EVALUASI KOMPETENSI KEAHLIAN TEKNIK PEMESINAN DI SMK
}

\author{
Fajar Satriya Hadi \\ Amat Mukhadis \\ Amat Nyoto
}

\begin{abstract}
Abstrak: Tujuan penelitian ini untuk memerikan hambatan dan faktor penyebab praktik kerja industri siswa SMK Kompetensi keahlian Teknik Pemesinan pada tahap: persiapan, pelaksanaan, dan evaluasi. Menggunakan metode penelitian deskriptif kuantitatif. Menggunakan ketentuan proporsional random sampling jumlah sampel adalah: sebanyak 82 siswa, 10 guru, 6 instruktur industri. Teknik pengumpulan data dilakukan dengan observasi, kuesioner, dan wawancara. Hasil penelitian: (1) hambatan pada tahap persiapan: (a) siswa kesulitan mencari tempat prakerin yang sesuai dengan bakat, minat, dan keahlian; (b) kesulitan mencari tempat tinggal sementara/kos; (2) hambatan pada tahap pelaksaan: (a) tidak relevannya keahlian dengan pekerjaan dan tugas yang dikerjakan siswa di tempat prakerin; (b) kedisiplinan siswa yang rendah; (c) penerapan K3 yang tidak sesuai SOP; (3) hambatan pada tahap evaluasi kesulitan pada perencanaan karir siswa.
\end{abstract}

Kata-kata Kunci: praktik indusri, DU/DI, keahlian teknik pemesinan, SMK

Abstract: The Industrial Work Practices Obstacles and its Causal Factors Reviewed from Preparation, Implementation, and Evaluation of Machining Engineering Competence Skills in SMK. The purpose of this research was to describe the industrial work practices obstacles and its causal factors of SMK students Competence of Machining Engineering skills during the stage of preparation, implementation and evaluation. The study uses the quantitative descriptive research method. Data was collected by using proportional random sampling. The samples consists 82 students, 10 teachers, and 6 industrial instructors. Data collection techniques were conducted by observation, questionnaires, and interviews. The results of the study: (1) the obstacles in the preparation stage includes: (a) students have difficulty on finding internship places that is accordance to their talents, interests and skills; (b) difficulty on finding temporary accommodation / boarding halls; (2) the obstacles at the stage of implementation includes: (a) irrelevance of skills with work and tasks undertaken by students during industrial practices; (b) low student discipline; (c) the implementation of OSH that does not comply with the SOP; (3) the obstacles at the evaluation stage are difficulties on student career planning.

Keywords: industrial practice, DU/DI, machining engineering skills, SMK 
kriteria kebutuhan kerja yang ada di Dunia Industri (DU/DI). Lulusan SMK diharapkan menjadi tenaga kerja tingkat menengah sesuai dengan kompetensi dalam program studi keahlian yang dipilihan dan diminatinya. Disamping itu lulusan juga dibekali dengan ilmu pengetahuan, teknologi, dan seni agar mampu mengembangkan diri secara mandiri ataupun melanjutkan ke jenjang pendidikan yang lebih tinggi, sesuai dengan Peraturan Pemerintah Republik Indonesia Nomor 29 tahun 1990 disebutkan dalam Pasal 1 Ayat 3 bahwa pendidikan menengah kejuruan adalah pendidikan pada jenjang pendidikan menengah yang mengutamakan pengembangan kemampuan siswa untuk melaksanakan jenis pekerjaan tertentu. Hal ini relevan dengan, Pasal 3 Ayat 2 disebutkan bahwa pendidikan menengah kejuruan mengutamakan penyiapan siswa untuk memasuki lapangan kerja serta mengembangkan sikap profesional.

Menurut Sistem Pendidikan Nasional No. 20 Tahun 2003 tujuan pendidikan kejuruan adalah satuan pendidikan menengah kejuruan sebagai lanjutan dari pendidikan dasar yang bertujuan mempersiapkan peserta didik atau lulusan terutama dalam bidang tertentu. Oleh karena itu SMK dirancang yang siap memasuki dunia kerja dan mampu mengembangkan sikap professional di bidang pekerjaan sesuai dengan keahliannya. Meningkatkan kesempatan kerja untuk lulusan pendidikan menengah kejuruan merupakan masalah pendidikan kejuruan saat ini yang perlu mendapat perhatian lebih, jika mengingat bahwa SMK merupakan lembaga pendidikan kejuruan yang berpotensi untuk mempersiapkan SDM yang dapat terserap oleh dunia kerja (Jatmoko, 2013). Hal ini dapat dilihat dari materi teori dan praktik yang bersifat aplikatif telah diberikan sejak awal masuk SMK dengan harapan lulusan SMK memiliki kompetensi sesuai dengan kebutuhan dunia kerja.
Badan Pusat Statistik (BPS) mencatat angka pengangguran bertambah 300.000 orang menjadi 7,45 juta orang per Februari 2015. Kondisi ini seiring dengan perlambatan ekonomi yang terjadi pada kuartal I-2015 hanya 4,71\%. Pengangguran paling besar terjadi pada masyarakat berpendidikan dengan lulusan SMK, yaitu sebesar 9,05\%. Dibandingkan dengan Februari 2014, juga ada kenaikan 1,84 poin. Selanjutnya, pengangguran terbesar adalah lulusan SMA dengan porsi $8,17 \%$. Untuk Diploma I/II/III porsi pengangguran adalah sebesar $7,49 \%$. Dari data yang didapat dari BPS menunjukkan bahwa tingkat pengangguran SMK yang paling besar jika dibandingkan dengan lulusan yang lainnya (Jefriando, 2015). SMK perlu mengintegrasikan materi teori atau praktik kejuruan dengan kompetensi yang ada di industri agar dapat mengevaluasi program, isi program, pelaksanaan, dalam memperbarui kurikulum secara berkesinambungan (Jatmoko, 2013). Pendidikan kejuruan harus mampu membekali lulusan dengan kompetensi yang dibutuhkan untuk kebutuhan masa depan siswa dengan melihat realita dunia kerja dan teknologi yang berkembang saat ini.

Prakerin merupakan program yang ditempuh oleh siswa SMK kelas XI. Dari segi persiapan, pelaksanaan dan evaluasinya harus matang dan efektif sehingga pelaksanaan prakerin siswa SMK kelas XI tepat sasaran. Hambatan pun sering ditemui siswa dalam praktik kerja industri, sehingga pada pelaksanaanya saat ini siswa mengalami kesulitan, baik pada persiapan, pelaksanaan, maupun evaluasinya. Hasil wawancara dengan guru SMK di Blitar menunjukan bahwa pemenuhan tempat praktek kerja indutri diserahkan pada siswa kelas XI, namun realitanya karena kurang koordinasi dengan guru pembimbing prakerin banyak siswa yang mendapatkan tempat prakerin tidak sesuai dengan kompetensi keahlianya. 
Guru SMK di Blitar mengatakan, siswa teknik elektronika konsentrasi keahlian arus lemah, mendapat tempat prakerin di PLN, dimana mereka ditempatkan di instalasi listrik yang merupakan konsentrasi keahlian arus kuat. Hal ini perlu adanya solusi sehingga siswa yang prakerin harus match antara tempat prakerin dengan kompetensi siswa. Menurut Mulyani (2011) pekerjaan yang dikerjakan siswa prakerin perlu kiranya sinkronisasi ulang tentang kompetensi-kompetensi yang diajarkan di sekolah maupun di industri, jika pelaksanaannya sudah sesuai maka ini sejalan dengan salah satu tujuan prakerin.

Hambatan dalam prakerin secara spesifik dapat diungkapkan dari beberapa aspek: (1) kendala peserta didik, kurangnya pengarahan, perintah yang bertubitubi, materi pelajaran di sekolah yang berbeda dengan keadaan dilapangan; (2) kendala pembimbing, harus membimbing secara intensif (Prasetyo, 2013). Indriyanto (2011) menambahkan dalam penelitiannya bahwa hambatan yang dihadapi oleh SMK N 5 Surakarta khususnya Kompetensi Keahlian Teknik Bangunan antara lain: (1) jenis pekerjaan yang diberikan kepada siswa prakerin kurang sesuai dengan kompetensi yang dimiliki; (2) tempat prakerin yang jauh dari tempat tinggal siswa mengakibatkan siswa kesulitan menuju tempat prakerin; (3) kurang optimalnya pembimbingan yang dilakukan oleh pihak sekolah.

Hambatan-hambatan di atas harus segera diatasi mengingat tujuan pendidikan kejuruan yang memper-siapkan pekerja dengan kompetensi yang sesuai dengan DU/DI. Ditinjau dari evaluasi juga ditemukan hambatan terkait penilaian. Menurut penelitian Soraya (2013) ada beberapa hambatan penilaian prakerin instrument penilaian kinerja prakerin yang digunakan, masih ada beberapa bagian yang seharusnya ada tetapi tidak ada dalam instrumen penilaian. Berdasarkan pemapar- an tersebut, peneliti mengambil penelitian dengan judul hambatan dan faktor penyebabnya prakerin ditinjau dari tahap persiapan, pelaksanaan, dan evaluasi siswa smk kompetensi keahlian teknik pemesinan diharapkan dari hasil penelitian dapat memberikan kontribusi yang efektif dan signifikan untuk pendidikan kejuruan khususnya SMK pada bidang prakerin sehingga diharapkan membantu siswa dalam memecahkan persoalan pada saat siswa SMK melakukan praktik kerja industri.

\section{METODE}

Penelitian ini merupakan penelitian deskriptif kuantitatif, menurut Mukhadis (2016:70) penelitian kuantitatif adalah penelitian yang tuntutan kedalaman dalam melakukan analisis data sebagai wahana memformulasikan interpretasi hanya sampai pada deskripsi, pemerian, pemetaan, dari variabel yang dijadikan hanya objek satu demi satu. Populasi Penelitian ini adalah 408 siswa SMK kelas XII, 10 guru, 6 instruktur prakerin. Untuk menentukan jumlah sampel siswa menggunakan teknik proporsional random sampling diperoleh 82 siswa SMK kelas XII, untuk sampel guru diambil semuanya 10 orang guru, dan untuk industri menggunakan teknik purposive sampling diperoleh 6 instruktur prakerin. instrumen penelitian ini adalah observasi, kuesioner dan wawancara. Analisis data menggunakan teknik statistik deskriptif dengan dengan rumus mean dan persentase. Proses analisis data dengan bantuan spss 21 for windows.

Tujuan penelitian ini untuk mengungkap dan memerikan hambatan dan faktor penyebab prakerin ditinjau dari tahap persiapan, tahap pelaksanaan, dan tahap evaluasi siswa SMK Kompetensi keahlian Teknik Pemesinan. 


\section{HASIL}

Hambatan prakerin yang dihadapi siswa Kompetensi Keahlian Teknik Pemesinan di SMK ditinjau dari tahap persiapan di industri (kecil, menengah, dan besar) disajikan pada Tabel 1 .
2,30 dan 57,00\% kategori mudah, untuk industri besar dengan rerata 2,40 dan persentase $60,00 \%$ kategori mudah. Secara keseluruhan dapat diinterpretasikan tidak ada hambatan; (4) Pembekalan guru atau DU/DI untuk industri kecil dengan rerata

Tabel 1. Hambatan Prakerin pada Tahap Persiapan dengan Sumber Data Siswa

\begin{tabular}{|c|c|c|c|c|c|c|c|c|c|c|}
\hline \multirow[t]{3}{*}{ No } & \multirow[t]{3}{*}{ Indikator } & \multicolumn{9}{|c|}{ DU/DI } \\
\hline & & \multicolumn{3}{|c|}{ Industri Kecil } & \multicolumn{3}{|c|}{ Industri Menengah } & \multicolumn{3}{|c|}{ Industri Besar } \\
\hline & & $\begin{array}{l}\text { Per- } \\
\text { sentase } \\
(\%)\end{array}$ & Mean & $\begin{array}{c}\text { Kate- } \\
\text { gori }\end{array}$ & $\begin{array}{l}\text { Persen- } \\
\text { tase } \\
(\%)\end{array}$ & Mean & $\begin{array}{l}\text { Kate- } \\
\text { gori }\end{array}$ & $\begin{array}{l}\text { Persen- } \\
\text { tase } \\
(\%)\end{array}$ & Mean & $\begin{array}{c}\text { Kate- } \\
\text { gori }\end{array}$ \\
\hline 1 & $\begin{array}{l}\text { Perencanaan } \\
\text { Waktu }\end{array}$ & 44,00 & 1,76 & Mudah & 48,00 & 1,94 & Mudah & 47,00 & 1,88 & Mudah \\
\hline 2 & $\begin{array}{l}\text { Perencanaan } \\
\text { Tempat } \\
\text { Prakerin }\end{array}$ & 46,00 & 1,86 & Mudah & 46,00 & 1,84 & Mudah & 47,00 & 1,88 & Mudah \\
\hline 3 & $\begin{array}{l}\text { Perencanaan } \\
\text { Akomodasi } \\
\text { Siswa/Siswi }\end{array}$ & 50,00 & 2,00 & Mudah & 57,00 & 2,30 & Mudah & 60,00 & 2,40 & Mudah \\
\hline 4 & $\begin{array}{l}\text { Pembekalan } \\
\text { dari Guru } \\
\text { atau DU/DI }\end{array}$ & 38,00 & 1,50 & $\begin{array}{l}\text { Sangat } \\
\text { Mudah }\end{array}$ & 36,00 & 1,44 & $\begin{array}{l}\text { Sangat } \\
\text { mudah }\end{array}$ & 33,00 & 1,31 & $\begin{array}{l}\text { Sangat } \\
\text { mudah }\end{array}$ \\
\hline & Total & 45,00 & 1,78 & Mudah & 48,00 & 1,88 & Mudah & 47,00 & 1,86 & Mudah \\
\hline
\end{tabular}

Tabel 1 menunjukkan bahwa: (1) perencanaan waktu di industri kecil dengan rerata 1,80 dan persentase $44,00 \%$ kategori mudah, untuk industri menengah dengan rerata 1,94 dan persentase $48,00 \%$ kategori mudah, untuk industri besar dengan rerata 1,88 dan persentase $45,00 \%$ kategori mudah. Secara keseluruhan dapat diinterpretasikan tidak ada hambatan; (2) Perencanaan tempat prakerin industri kecil dengan rerata 1,86 dan persentase $46,00 \%$ kategori mudah, industri menengah dengan rerata 1,84 dan persentase $46,00 \%$ kategori mudah, industri besar dengan rerata 1,88 dan persentase $47,00 \%$ kategori mudah. Secara keseluruhan dapat diinterpretasikan tidak ada hambatan; (3) Perencanaan akomodasi siswa indutri kecil dengan rerata 2,00 dan persentase $50,00 \%$, untuk industri menengah dengan persentase dengan rerata
1,50 dan persentase $38,00 \%$ kategori mudah, industri menengah dengan rerata 1,44 dan persentase $36,00 \%$ kategori mudah, dan industri besar dengan rerata 1,31 dan persentase $33,00 \%$ kategori mudah. Secara keseluruhan dapat diinterpretasikan tidak ada hambatan. Adapun total indikator di industri kecil rerata 1,78 dan persentase $45,00 \%$, industri menengah rerata 1,88 dan persentase $48,00 \%$, dan industri besar rerata 1,86 dan persentase $47,00 \%$ kategori mudah, sehingga dapat dikatakan tidak ada hambatan Prakerin ditinjau dari tahap persiapan tidak ada hambatan menurut siswa baik di industri kecil, menengah, maupun besar.

Hambatan prakerin yang dihadapi siswa Kompetensi Keahlian Teknik Pemesinan di SMK ditinjau dari tahap pelaksanaan di industri (kecil, menengah, dan besar) disajikan pada Tabel 2 . 
Tabel 2 menunjukkan bahwa: (1) kondisi kesehatan siswa di industri kecil dengan rerata 1,30 dan persentase $33,00 \%$ kategori sangat mudah, di industri menengah dengan rerata 1,60 dan persentase $40,00 \%$ kategori sangat mudah, untuk industri besar dengan rerata 1,60 dan persentase $41,00 \%$ kategori sangat mudah. Secara keseluruhan dapat diinterpretasikan kondisi kesehatan tidak ada hambatan; (2) fasilitas yang diterima siswa untuk industri kecil dengan rerata 3,11 dan persentase $78,00 \%$ kategori sulit, sehingga dikatakan ada hambatan tentang fasilitas prakerin yang digunakan siswa. Di industri menengah dengan rerata 2,00 persentase dan 50,00\% kategori mudah; dan di industri besar dengan rerata 1,05 dan persentase $26,00 \%$ kategori mudah, sehingga dikatakan tidak ada hambatan tentang fasilitas yang digunakan siswa; (3) hubungan siswa prakerin baik dengan siswa maupun karyawan di industri kecil dengan rerata 1,60 dan persentase $40,00 \%$ kategori sangat mudah, di industri menengah dengan rerata 1,40 dan persentase $34,00 \%$ kategori sangat mudah, dan industri besar dengan rerata 1,40 dan persentase $35,00 \%$ kategori sangat mudah, sehingga dapat dikatakan tidak ada hambatan hubungan siswa prakerin baik dengan siswa maupun karyawan industri; (4) kompetensi yang diterima siswa di industri kecil dengan rerata 2,52 dan persentase $63,00 \%$ kategori sulit, di industri menengah dengan rerata 2,60 dan persentase $64,00 \%$ kategori sulit, dan industri besar dengan rerata 2,54

Tabel 2. Hambatan Prakerin Ditinjau dari Tahap Pelaksanaan dengan Sumber Data Siswa

\begin{tabular}{|c|c|c|c|c|c|c|c|c|c|c|}
\hline \multirow[t]{3}{*}{ No } & \multirow[t]{3}{*}{ Indikator } & \multicolumn{9}{|c|}{ DU/DI } \\
\hline & & \multirow{2}{*}{$\begin{array}{c}\text { Ind } \\
\text { Persen- } \\
\text { tase } \\
(\%)\end{array}$} & \multicolumn{2}{|c|}{ dustri Kecil } & \multicolumn{3}{|c|}{ Industri Menengah } & \multicolumn{3}{|c|}{ Industri Besar } \\
\hline & & & Mean & $\begin{array}{l}\text { Kate- } \\
\text { gori }\end{array}$ & $\begin{array}{l}\text { Persen- } \\
\text { tase } \\
(\%)\end{array}$ & Mean & $\begin{array}{l}\text { Kate- } \\
\text { gori }\end{array}$ & $\begin{array}{l}\text { Persen- } \\
\text { tase } \\
(\%)\end{array}$ & Mean & $\begin{array}{c}\text { Kate- } \\
\text { gori }\end{array}$ \\
\hline 1 & $\begin{array}{l}\text { Kondisi } \\
\text { Kesehatan Siswa }\end{array}$ & 33,00 & 1,30 & $\begin{array}{l}\text { Sangat } \\
\text { mudah }\end{array}$ & 40,00 & 1,60 & $\begin{array}{l}\text { Sangat } \\
\text { mudah }\end{array}$ & 41,00 & 1,60 & $\begin{array}{l}\text { Sangat } \\
\text { mudah }\end{array}$ \\
\hline 2 & $\begin{array}{l}\text { Fasilitas yang } \\
\text { Diterima Siswa }\end{array}$ & 78,00 & 3,11 & Sulit & 50,00 & 2,00 & Mudah & 26,00 & 1,05 & $\begin{array}{l}\text { Sangat } \\
\text { mudah }\end{array}$ \\
\hline 3 & $\begin{array}{l}\text { Hubungan Siswa } \\
\text { Prakerin Baik } \\
\text { dengan Siswa } \\
\text { maupun } \\
\text { Karyawan } \\
\text { Industri }\end{array}$ & 40,00 & 1,60 & $\begin{array}{l}\text { Sangat } \\
\text { mudah }\end{array}$ & 34,00 & 1,40 & $\begin{array}{l}\text { Sangat } \\
\text { mudah }\end{array}$ & 35,00 & 1,40 & $\begin{array}{l}\text { Sangat } \\
\text { mudah }\end{array}$ \\
\hline 4 & $\begin{array}{l}\text { Kompetensi yang } \\
\text { Diterima Siswa di } \\
\text { Tempat Prakerin }\end{array}$ & 63,00 & 2,52 & Sulit & 64,00 & 2,60 & Sulit & 63,00 & 2,54 & Sulit \\
\hline 5 & $\begin{array}{l}\text { Pelaksanaan } \\
\text { Prakerin }\end{array}$ & 47,00 & 1,90 & Mudah & 40,00 & 1,60 & $\begin{array}{l}\text { Sangat } \\
\text { mudah }\end{array}$ & 34,00 & 1,40 & $\begin{array}{l}\text { Sangat } \\
\text { mudah }\end{array}$ \\
\hline 6 & $\begin{array}{l}\text { Kedisiplinan } \\
\text { Siswa }\end{array}$ & 48,00 & 1,90 & Mudah & 44,00 & 1,80 & Mudah & 29,00 & 1,20 & $\begin{array}{l}\text { Sangat } \\
\text { mudah }\end{array}$ \\
\hline 7 & $\begin{array}{l}\text { Bimbingan dan } \\
\text { Monitoring yang } \\
\text { Dilakukan oleh } \\
\text { Sekolah }\end{array}$ & 34,00 & 1,30 & $\begin{array}{l}\text { Sangat } \\
\text { mudah }\end{array}$ & 38,00 & 1,50 & $\begin{array}{l}\text { Sangat } \\
\text { Mudah }\end{array}$ & 34,00 & 1,30 & $\begin{array}{l}\text { Sangat } \\
\text { mudah }\end{array}$ \\
\hline & Total & 50,00 & 2,00 & Mudah & 50,00 & 2,00 & Mudah & 38,00 & 1,50 & $\begin{array}{l}\text { Sangat } \\
\text { mudah }\end{array}$ \\
\hline
\end{tabular}


dan persentase $63,00 \%$ kategori sulit, sehingga dikatakan ada hambatan dalam hal kompetensi siswa, baik di industri kecil, menengah, maupun industri besar; (5) pelaksanaan prakerin untuk industri kecil dengan rerata 1,90 dan persentase $47,00 \%$ kategori mudah, di industri menengah dengan rerata 1,60 dan persentase $40,00 \%$ kategori sangat mudah, dan di industri besar dengan rerata 1,40 dan persentase $34,00 \%$ kategori sangat mudah, sehingga dapat dikatakan pelaksanaan prakerin bagi siswa tidak ada hambatan; (6) kedisiplinan siswa di industri kecil dengan rerata 1,90 dan persentase $48,00 \%$ kategori mudah, industri menengah dengan rerata 1,80 dan persentase $44,00 \%$ kategori mudah, dan di industri besar dengan rerata 1,20 dan persentase $29,00 \%$ kategori mudah, sehingga kondisi kesehatan siswa prakerin tidak ada hambatan; (7) bimbingan dan monitoring yang dilakukan oleh sekolah dan DU/DI di industri kecil dengan rerata 1,30 dan persentase $34,00 \%$ kategori mudah, di industri menengah dengan rerata 1,50 dan persentase 38,00\% kategori mudah, dan di industri besar dengan rerata 1,3 dan persentase $34,00 \%$ kategori mudah, sehingga bimbingan dan monitoring yang dilakukan oleh sekolah dan DU/DI tidak ada hambatan. Ada persentase hambatan pada fasilitas prakeri, tetapi secara umum dapat dikatakan bahwa pelaksanaan prakerin siswa di industri kecil, menengah, dan besar tidak ada hambatan.

Hambatan prakerin yang dihadapi siswa Kompetensi Keahlian Teknik Pemesinan di SMK ditinjau dari tahap evaluasi di industri (kecil, menengah, dan besar) disajikan pada Tabel 3. Tabel 3 menunjukkan bahwa: (1) kesesuaian kompetensi yang diujikan terhadap kompetensi yang diperoleh pada saat prakerin di industri kecil dengan rerata 1,50 dan persentase $37,00 \%$ kategori mudah, di industri menengah dengan dengan rerata 1,80 dan persentase $40,00 \%$ kategori mudah, dan di industri besar dengan rerata 1,30 dan persentase $33,00 \%$ kategori mudah, sehingga dapat dikatakan tidak ada hambatan tentang kesesuaian kompetensi yang diujikan dengan kompetensi yang diperoleh saat prakerin; (2) refleksi prakerin di industri kecil dengan rerata 1,45 dan persentase $36,00 \%$ kategori mudah, di industri menengah dengan rerata 2,20 dan persentase $55,00 \%$ kategori mudah,

Tabel 3. Hambatan Prakerin Ditinjau dari Tahap Evaluasi dengan Sumber Data Siswa

\begin{tabular}{|c|c|c|c|c|c|c|c|c|c|c|}
\hline \multirow[t]{3}{*}{ No } & \multirow[t]{3}{*}{ Indikator } & \multicolumn{9}{|c|}{ DU/DI } \\
\hline & & \multicolumn{3}{|c|}{ Industri Kecil } & \multicolumn{3}{|c|}{ Industri Menengah } & \multicolumn{3}{|c|}{ Industri Besar } \\
\hline & & $\begin{array}{c}\text { Persen- } \\
\text { tase } \\
(\%)\end{array}$ & Mean & $\begin{array}{l}\text { Kate- } \\
\text { gori }\end{array}$ & $\begin{array}{l}\text { Persen- } \\
\text { tase }(\%)\end{array}$ & Mean & $\begin{array}{l}\text { Kate- } \\
\text { gori }\end{array}$ & $\begin{array}{l}\text { Persen- } \\
\text { tase }(\%)\end{array}$ & Mean & $\begin{array}{l}\text { Kate- } \\
\text { gori }\end{array}$ \\
\hline 1 & $\begin{array}{l}\text { Kesesuaian } \\
\text { Kompetensi } \\
\text { yang Diujikan } \\
\text { terhadap } \\
\text { Kompetensi } \\
\text { yang Diperoleh } \\
\text { pada saat } \\
\text { Prakerin }\end{array}$ & 37,00 & 1,50 & $\begin{array}{l}\text { Sangat } \\
\text { mudah }\end{array}$ & 40,00 & 1,80 & Mudah & 33,00 & 1,30 & $\begin{array}{l}\text { Sangat } \\
\text { mudah }\end{array}$ \\
\hline 2 & $\begin{array}{l}\text { Refleksi } \\
\text { Prakerin }\end{array}$ & 36,00 & 1,45 & $\begin{array}{l}\text { Sangat } \\
\text { mudah }\end{array}$ & 55,00 & 2,20 & Mudah & 41,00 & 1,60 & $\begin{array}{l}\text { Sangat } \\
\text { Mudah }\end{array}$ \\
\hline 3 & $\begin{array}{l}\text { Tindak Lajut } \\
\text { Prakerin }\end{array}$ & 51,00 & 2,00 & Mudah & 56,00 & 2,20 & Mudah & 51,00 & 2,00 & Mudah \\
\hline & Total & 41,00 & 1,65 & Mudah & 51,00 & 2,10 & Mudah & 42,00 & 1,60 & Mudah \\
\hline
\end{tabular}


dan di industri besar dengan rerata 1,60 dan persentase $41,00 \%$ kategori mudah, sehingga dapat dikatakan tidak ada hambatan tentang refleksi prakerin; (3) tindak lanjut prakerin di industri kecil dengan rerata 2,10 dan persentase $51,00 \%$ kategori mudah, di industri menengah dengan rerata 2,20 dan persentase $56,00 \%$ kategori mudah, dan di industri besar dengan rerata 1,60 dan persentase $42,00 \%$ kategori mudah, sehingga dapat dikatakan tidak ada hambatan tentang tindak lajut prakerin. Ada persentase hambatan dalam hal kompetensi yang diperoleh siswa, namun secara umum dapat dikatakan bahwa pada tahapan evaluasi prakerin siswa di industri kecil, menengah, dan besar tidak ada hambatan.

Hambatan prakerin siswa SMK Kompetensi Keahlian Teknik Pemesinan ditinjau dari tahap persiapan di industri (kecil, menengah, dan besar) dengan sumber data guru disajikan pada Tabel 4. perencanaan tempat prakerin dengan rerata 1,80 dan persentase $45,00 \%$ kategori mudah, sehingga dapat dikatakan tidak ada hambatan bagi guru pada perencanaan tepat prakerin; (3) kerjasama antara pihak sekolah dengan DU/DI dengan rerata 1,80 dan persentase $45,00 \%$ kategori mudah, sehingga dapat dikatakan tidak ada hambatan bagi guru pada kerjasama antara pihak sekolah dengan DU/DI; (4) perencanaan akomodasi siswa dengan rerata 3,35 dan persentase $84,00 \%$ kategori sangat sulit, Sehingga dapat dikatakan ada hambatan bagi guru pada perencanaan akomodasi siswa; dan (5) pembekalan siswa dengan rerata 1,30 dan persentase $33,00 \%$ kategori sangat mudah, sehingga dapat dikatakan tidak ada hambatan bagi guru pada pembekalan siswa. Secara umum dapat dikatakan bahwa pada tahapan persiapan prakerin siswa bagi guru di industri kecil, menengah, dan besar tidak ada hambatan.

Tabel 4. Hambatan Prakerin Ditinjau dari Tahap Persiapan dengan Sumber Data Guru

\begin{tabular}{llccc}
\hline No & \multicolumn{1}{c}{ Indikator } & \multicolumn{3}{c}{ Guru } \\
\cline { 3 - 5 } & & $\begin{array}{c}\text { Persentase } \\
(\mathbf{\%})\end{array}$ & Mean & Kategori \\
\hline 1 & Perencanaan Waktu & 45,00 & 1,80 & Mudah \\
3 & Perencanaan Tempat Prakerin & 45,00 & 1,80 & Mudah \\
2 & Kerjasama antar Pihak Sekolah dengan DU/DI & 45,00 & 1,80 & Mudah \\
4 & Perencanaan Akomodasi Siswa & 84,00 & 3,35 & Sangat Sulit \\
5 & Pembekalan Siswa Prakerin & 33,00 & 1,30 & Sangat mudah \\
\hline & Total & 50,00 & 2,00 & Mudah \\
\hline
\end{tabular}

Tabel 5. Hambatan Prakerin Ditinjau dari Tahap Pelaksanaan dengan Sumber Data Guru

\begin{tabular}{|c|c|c|c|c|c|}
\hline \multirow[t]{2}{*}{ No } & \multirow{2}{*}{\multicolumn{2}{|c|}{ Indikator }} & \multicolumn{3}{|c|}{ Guru } \\
\hline & & & $\begin{array}{l}\text { Persentase } \\
(\%)\end{array}$ & Mean & Kategori \\
\hline 1 & Pelaksanaan Prakerin & & 38,00 & 1,50 & Sangat mudah \\
\hline 2 & $\begin{array}{l}\text { Bimbingan dan Monitoring yang Dilakuk } \\
\text { Sekolah }\end{array}$ & n oleh & 43,00 & 1,70 & Sangat mudah \\
\hline & Total & & 41,00 & 1,60 & Sangat Mudah \\
\hline $\begin{array}{l}\text { renc } \\
\text { pers } \\
\text { hing } \\
\text { an b }\end{array}$ & $\begin{array}{l}\text { Tabel } 4 \text { menunjukkan bahwa: (1) pe- } \\
\text { anaan waktu dengan rerata } 1,80 \text { dan } \\
\text { entase } 45,00 \% \text { kategori mudah, se- } \\
\text { ga dapat dikatakan tidak ada hambat- } \\
\text { agi guru pada perencanaan waktu. (2) }\end{array}$ & $\begin{array}{l}\text { Kom } \\
\text { ditin } \\
\text { (keci } \\
\text { sumb }\end{array}$ & $\begin{array}{l}\text { lambatan p } \\
\text { etensi Keahl } \\
\text { u dari tahap } \\
\text { menengah, } \\
\text { r data guru c }\end{array}$ & $\begin{array}{l}\text { akerin } \\
\text { an Tek } \\
\text { gelaksa } \\
\text { dan } \\
\text { isajikar }\end{array}$ & $\begin{array}{l}\text { siswa SMK } \\
\text { hik Pemesinan } \\
\text { aan di industri } \\
\text { esar) dengan } \\
\text { pada Tabel } 5 .\end{array}$ \\
\hline
\end{tabular}


Tabel 5 menunjukkan bahwa: (1) pelaksanaan prakerin dengan rerata 1,50 dan persentase $38,00 \%$ kategori sangat mudah, sehingga dapat dikatakan tidak ada hambatan bagi guru pada pelaksanaan prakerin; (2) Bimbingan dan monitoring yang dilakukan oleh sekolah dengan rerata 1,70 dan persentase $43,00 \%$ kategori mudah, sehingga dapat dikatakan tidak ada hambatan bagi guru pada bimbingan dan monitoring. Adapun total keseluruhan indikator dengan rerata1,60 dan persentase $41,00 \%$ kategori sangat mudah. Secara umum dapat dikatakan bahwa pada tahapan pelaksanan prakerin siswa bagi guru di industri kecil, menengah, dan besar tidak ada hambatan.

Hambatan prakerin siswa SMK Kompetensi Keahlian Teknik Pemesinan ditinjau dari tahap evaluasi di industri (kecil, menengah, dan besar) dengan sumber data guru disajikan pada Tabel 6 . Tabel 6 menunjukkan bahwa (1) bentuk evaluasi dengan rerata 2,30 dan persentase $58,00 \%$ kategori mudah, sehingga dapat dikatakan tidak ada hambatan bagi guru pada bentuk evaluasi; (2) kesesuaian kompetensi yang diujikan dengan kompetensi yang diperoleh pada saat prakerin rerata 1,70 dan persentase $42,00 \%$ kategori sangat mudah, sehingga dapat dikatakan tidak ada hambatanbagi guru pada kesesuaian kompetensi yang diujikan dengan kompetensi yang diperoleh pada saat prakerin; (3) refleksi prakerin dengan rerata 1,30 dan persentase $33,00 \%$ kategori sangat mudah, sehingga dapat dikatakan tidak ada hambatan bagi guru pada refleksi prakerin; (4) tindak lanjut prakerin dengan rerata 1,95 dan persentase $49,00 \%$ kategori mudah, sehingga dapat dikatakan tidak ada hambatan bagi guru pada tindak lanjut prakerin. Adapun total keseluruhan indikator dengan rerata1,8 dan persentase $46,00 \%$ kategori mudah. Secara umum dapat dikatakan bahwa pada tahapan evaluasi prakerin siswa bagi guru di industri kecil, menengah, dan besar tidak ada hambatan.

Tabel 6. Hambatan prakerin Ditinjau dari Tahap Evaluasi dengan Sumber Data Guru

\begin{tabular}{llccc}
\hline No & \multicolumn{1}{c}{ Indikator } & \multicolumn{3}{c}{ Guru } \\
\cline { 3 - 5 } & & $\begin{array}{c}\text { Persentase } \\
(\mathbf{\%})\end{array}$ & Mean & Kategori \\
\hline 1 & Bentuk Evaluasi & $58 \%$ & 2,30 & Mudah \\
2 & Kesesuaian Kompetensi yang Diujikan terhadap & $42 \%$ & 1,70 & Sangat mudah \\
& Kompetensi Diperoleh pada Saat Prakerin & & & \\
3 & Refleksi Prakerin & $33 \%$ & 1,30 & Sangat mudah \\
4 & Tindak Lajut Prakerin & $49 \%$ & 1,95 & Mudah \\
\hline & Total & $46 \%$ & 1,80 & Mudah \\
\hline
\end{tabular}

Tabel 7. Hambatan Prakerin Ditinjau dari Tahap Persiapan dengan Sumber Data Instruktur

\begin{tabular}{llccc}
\hline No & \multicolumn{1}{c}{ Indikator } & \multicolumn{3}{c}{ Instruktur Industri } \\
\cline { 3 - 5 } & & 44,00 & 1,77 & Mudah \\
\hline 1 & Kerjasama antar Pihak Sekolah dengan & & & \\
& DU/DI & 46,00 & 1,80 & Mudah \\
2 & Perencanaan Waktu & 46,00 & 1,80 & Mudah \\
3 & Perencanaan Kurikulum/ & & & \\
& Kompetensi & 94,00 & 3,75 & Sangat Sulit \\
4 & Perencanaan Akomodasi Siswa & 33,00 & 1,30 & Sangat Mudah \\
5 & Pembekalan Siswa & 53,00 & 2,00 & Mudah \\
\hline
\end{tabular}


Hambatan prakerin siswa SMK Kompetensi Keahlian Teknik Pemesinan ditinjau dari tahap persiapan di industri (kecil, menengah, dan besar) dengan sumber data instruktur prakerin disajikan pada Tabel 7. Tabel 7 menunjukkan bahwa: (1) kerjasama antar pihak sekolah dan DU/ DI dengan rerata 1,77 dan persentase $44,00 \%$ kategori mudah, sehingga dapat dikatakan tidak ada hambatan bagi instruktur pada kerjasama antar pihak sekolah dengan DU/DI; (2) perencanaan waktu yang dilakukan oleh sekolah dengan rerata 1,80 dan persentase $43,00 \%$ kategori mudah, sehingga dapat dikatakan tidak ada hambatan bagi instruktur pada perencanaan waktu; (3) perencanaan kurikulum yang dilakukan oleh sekolah dengan rerata 1,80 dan persentase $43,00 \%$ kategori mudah, sehingga dapat dikatakan tidak ada hambatan bagi instruktur pada perencanaan kurikulum prakerin; (4) perencanaan akomodasi siswa dengan rerata 3,75 dan persentase 94,00\% kategori mudah, sehingga dapat dikatakan ada hambatan pada perencana- an akomodasi siswa; dan (5) pembekalan siswa dengan rerata 1,30 dan persentase $33,00 \%$ kategori mudah, sehingga dapat dikatakan tidak ada hambatan bagi instruktur pada pembekalan siswa. Secara umum dapat dikatakan bahwa pada tahapan persiapan prakerin siswa bagi instruktur di industri kecil, menengah, dan besar tidak ada hambatan.

Hambatan prakerin siswa SMK Kompetensi Keahlian Teknik Pemesinan ditinjau dari tahap pelaksanaan di industri (kecil, menengah, dan besar) dengan Sumber Data Instrktur Prakerin disajikan pada Tabel 8. Tabel 8 menunjukkan bahwa: (1) fasilitas yang diterima Siswa dengan rerata 2,75 dan persentase $67,00 \%$ kategori mudah, sehingga dapat dikatakan tidak ada hambatan bagi instruktur pada fasilitas yang diterima siswa; (2) kompetensi yang diterima siswa dengan rerata 1,70 dan persentase $42,00 \%$ kategori mudah, sehingga dikatakan tidak ada hambatan bagi instruktur pada kompetensi yang diterima siswa; (3) pelaksanaan prakerin dengan rerata 1,60 dan persen-

Tabel 8. Hambatan Prakerin Ditinjau dari Tahap Pelaksanaan dengan Sumber Data Instruktur Prakerin

\begin{tabular}{llccc}
\hline No & \multicolumn{1}{c}{ Indikator } & \multicolumn{3}{c}{ Instruktur Industri } \\
\cline { 3 - 5 } & & Persentase (\%) & Mean & Kategori \\
\hline 1 & Fasilitas yang Diterima Siswa & 67,00 & 2,75 & Sulit \\
2 & Kompetensi yang Diterima Siswa & 42,00 & 1,70 & Sangat Mudah \\
3 & Pelaksanaan Prakerin & 40,00 & 1,60 & Sangat Mudah \\
4 & Bimbingan dan Monitoring yang Dilakukan & 33,00 & 1,30 & Sangat Mudah \\
& Guru atau DU/DI & & & \\
\hline & Total & 44,00 & 1,80 & Mudah \\
\hline
\end{tabular}

Tabel 9. Hambatan Prakerin Ditinjau dari Tahap Evaluasi dengan Sumber Data Instruktur/Pembimbing Industri

\begin{tabular}{llccc}
\hline No & Indikator & \multicolumn{3}{c}{ Instruktur Industri } \\
\cline { 2 - 4 } & Persentase (\%) & Mean & Kategori \\
\hline 1 Bentuk Evaluasi & 42,00 & 1,70 & Mudah \\
2 & Kesesuaian Kompetensi yang Diujikan & 38,00 & 1,50 & Sangat Mudah \\
& terhadap Kompetensi yang Diperoleh pada & & & \\
& saat Prakerin & & & \\
3 & Refleksi Prakerin & 33,00 & 1,30 & Sangat Mudah \\
4 & Tindak Lanjut Prakerin & 36,00 & 1,40 & Sangat Mudah \\
\hline & Total & 37,00 & 1,50 & Mudah \\
\hline
\end{tabular}


tase $40,00 \%$ kategori mudah, sehingga dikatakan tidak ada hambatan bagi instruktur pada pelaksanaan prakerin; (4) bimbingan dan monitoring yang dilakukan Guru atau instruktur dengan rerata 1,30 dan persentase $33,00 \%$ kategori mudah, sehingga dapat dikatakan ada hambatan bagi guru atau instruktur pada bimbingan dan monitoring. yang dilakukan Guru atau DU/DI. Ada hambatan dalam persentase fasilitas, namun secara umum dapat dikatakan bahwa pada tahapan pelaksanaan prakerin siswa bagi instrukur di industri kecil, menengah, dan besar bagipara instruktur tidak ada hambatan.

Hambatan prakerin siswa SMK Kompetensi Keahlian Teknik Pemesinan ditinjau dari tahap evaluasi di industri (kecil, menengah, dan besar) dengan sumber data instrktur prakerin isajikan pada Tabel 9. Tabel 9 menunjukkan bahwa: (1) bentuk evaluasi dengan rerata 1,70 dan persentase $42,00 \%$ kategori mudah, sehingga dapat dikatakan tidak ada hambatan bagi instruktur pada bentuk evaluasi prakerin; (2) kesesuaian kompetensi yang diujikan dengan kompetensi diperoleh pada saat prakerin dengan rerata 1,50 dan persentase $38,00 \%$ kategori sangat mudah, sehingga dapat dikatakan tidak ada hambatan bagi instruktur pada kesesuaian kompetensi yang diujikan dengan kompetensi diperoleh pada saat prakerin; (3) refleksi prakerin dengan rerata 1,30 dan persentase 33,00\% kategori sangat mudah, sehingga dapat dikatakan tidak ada hambatan bagi instruktur pada refleksi prakerin; (4) tindak lanjut prakerin dengan rerata 1,40 dan persentase $36,00 \%$ kategori mudah, sehingga dapat dikatakan tidak ada hambatan bagi instruktur pada tindak lanjut prakerin. Secara umum dapat dikatakan bahwa pada tahapan evaluasi prakerin siswa bagi instruktur di industri kecil, menengah, dan besar bagi para instruktur tidak ada hambatan.

\section{PEMBAHASAN}

Hasil penelitian menunjukkan bahwa pada perencanaan waktu, siswa tidak mengalami hambatan baik yang melaksanakan prakerin di industri kecil, menengah, maupun besar. Hal ini dikarenakan sebelumnya siswa mendapat informasi pelaksanaan waktu prakerin dari guru, kakak kelas, dan media sekolah. Begitu juga menurut guru dan instrukturdalam perencanaan waktu prakerin tidak mengalami hambatan karena sudah ada kesepakatan dan komunikasi antara sekolah dan pihak DU/DI. Sebagaimana hasil penelitian Anik (2012) yang menyatakan bahwa hubungan kerjasama direncanakan secara tepat oleh pihak sekolah dan pihak industri, agar dapat terselenggara dengan efektif dan efisien. Jika kerjasama sudah direncanakan sebelum pelaksanaan prakerin maka dalam penyelenggaraannya tidak akan banak mengalami hambatan, sehingga menjadi efektif dan efisien.

Perencanaan tempat menurut siswa tidak ada hambatan, baik itu di industri kecil, menengah, maupun besar. Namun hasil wawancara dengan siswa menunjukkan bahwa terdapat siswa yang tidak mengetahui data/informasi lengkap industri/tempat prakerin yang akan di tempati. Hal ini disebabkan oleh sekolah kurang menjelaskan detail informasi tentang DU/DI yang akan menjadi tempat prakerin. Padahal kesesuaian tempat prakerin dengan siswa sangat penting dan berpengaruh pada hasil prakerin siswa. Sebagaimana penelitian Nidhom (2013) yang menyatakan bahwa ada hubungan yang signifikan antara kesesuaian tempat prakerin dengan hasil prakerin peserta didik kompetensi keahlian TKJ di SMK kota batu, kesesuaian tempat prakerin memberikan hasil positif terhadap hasil prakerin.

Perencanaan akomodasi di industri kecil menunjukkan tidak ada hambatan, sedangkan di industri menengah dan besar terdapat hambatan baik menurut sis- 
wa, guru, maupun instruktur.Temuan wawancara dengan siswa menunjukan bahwa terdapat siswa yang tidak mendapatkan tempat tinggal sementara/kos yang nyaman karena tempatnya bising dan tidak kondusif untuk dijadikan tempat tinggal. Adapun dari hasil wawancara dengan guru dan instruktur menyatakan bahwa pihak sekolah dan DU/DI tidak menyediakan akomodasi baik tempat tinggal maupun transportasi, hal ini disebabkan tidak adanya anggaran untuk akomodasi siswa.karena tidak disediakan oleh pihak sekolah dan DU/DI maka instruktur dan guru membantu mencarikan tempat tinggal untuk siswa.

Pembekalan prakerin menurut siswa, guru dan instruktur di industri kecil, menengah, dan besar tidak mengalami hambatan. Merujuk pada hasil kuesioner dan wawancara dengan guru dan instruktur, sebelum pelaksanaan prakerin guru dan instruktur selalu memberikan pembekalan pada siswa yang meliputi peraturan kerja, orientasi pekerjaan, K3 dan kedisiplinan. Pembekalan dilakukan sebelum prakerin sehingga dalam melaksanakannya tidak mendapatkan hambatan. Disamping itu untuk mencegah terjadinya kecelakaan kerja yang menimpa siswa baik yang sengaja maupun yang tidak sengaja.

Kerjasama antara pihak sekolah dengan DU/DI tidak ditemui hambatan. Temuan hasil wawancara dengan instruktur dalam pelaksanaan prakerin menunjukan bahwa tidak ada ikatan kerjasama antara industri kecil dan sekolah, hal ini dikarenakan kerjasama hanya sebatas percakapan saja tanpa adanya ikatan resmi. Adapun untuk industri menengah dan besar sudah diadakan Memo of Understanding (MoU) antara pihak sekolah dan DU/DI. Hal ini pun relevan dengan penelitian Anik (2012) dan Nayono (2012) yang menyatakan bahwa pelaksanaan kerjasama harus dilakukan dengan kreatif, inovatif, dan saling bersinergi untuk saling mengisi sehingga mempunyai nilai tambah untuk meningkatkan mutu pendidikan dan program prakerin. Ikatan kerjasama seperti MoU ini diperlukan, supaya kedua belah pihak tidak ada yang dirugikan. Hal ini relevan dengan penelitian Azizah (2015) yang menyatakan bahwa program kerjasama dengan DU/DI harus terus dibina secara berkesinambungan. Kerjasama yang dilaksanakan dengan dasar MoU harus disosialisasikan agar kedua belah pihak dapat melaksanakan hak dan kewajibannya secara tepat guna. Kerjasama yang mempunyai landasan yang kuat menjadikan kedua belah pihak melaksanakan hak dan kewajiban masingmasing sehingga diharapkan saling menguntungkan.

Hasil penelitian menunjukkan bahwa siswa mengalami hambatan di industri kecil yaitu pada aspek fasilitas prakerin yang diterima siswa. Hal ini disebabkan oleh tidak adanya fasilitas seperti tempat ibadah, kantin, serta unit kesehatan/klinik. Meskipun belum pernah ada kecelakaan kerja, unit kesehatan/klinik sangat diperlukan untuk merawat siswa atau karyawan yang mengalami kecelakakan kerja. Hasil penelitin ini bertentangan dengan penelitian Wahono (2014) yang menyampaikan bahwa sarana atau fasilitas belajar yang menunjang kegiatan belajar siswa dapat bermacam-macam bentuknya dan sarana belajar memegang peranan yang sangat penting dalam mendukung tercapainya keberhasilan belajar. Hal ini disebabkan oleh industri kecil hanya mempunyai modal, sarana dan prasarana yang terbatas. Sedangkan fasilitas umum tersedia di industri menengah dan besar. Industri kecil juga memiliki keterbatasan dalam menyediakan peralatan K3/Safety tool. Peralatan K3 sangat penting dalam aktivitas kerja untuk melindungi siswa dari kecelakaan kerja. Terdapat industri menengah dan besar yang tidak menyediakanperalatan K3 sehingga siswa menyediakan sendiri peralatan K3. 
Hal ini bertentangan dengan hasil penelitian Apriadi (2012) yang menyatakan bahwa sarana K3 sangat diperlukan dalam aktivitas sehari-hari mengingat dalam setiap aktivitas selalu terjadi kontak langsung dengan bahan kimia, bahan padat dan keras, debu, dan lain-lain. Sehingga diperlukan sarana untuk melindungi tubuh dari hal itu semua. Selain itu K3 juga merupakan salah satu SOP dalam melakukan aktivitas keahlian praktik industri.

Kompetensi yang diterima siswa di tempat prakerin menunjukkan ada hambatan. Terdapat siswa yang mengerjakan pekerjaan tidak sesuai dengan kompetensi keahlianya. Hal ini disebabkan karena kurangnya komunikasi antara pihak sekolah dengan DU/DI, pekerjaan yang dikerjakan siswa mengikuti aktivitas DU/DI dan belum adanya keterlibatan DU/DI dalam penyusunan kurikulum. Hal ini tidak relevan dengan penelitian Anik (2012) yang menyatakan bahwa cara belajar prakerin dengan berprinsip pada belajar sambil bekerja (Learning by doing) akan memungkinkan siswa lebih banyak memperoleh pengalaman lebih baik. Jika kompetensi antara DU/DI dengan sekolah tidak relevan, menyebabkan siswa kesulitan dalam mengembangkan keahliannya. Tujuan prakerin adalah menghasilkan tenaga kerja yang profesional memiliki pengetahuan, keterampilan, etos kerja sesuai kriteria dunia kerja. Sebagaimana penelitian Susanti (2015) yang menyatakan bahwa kesesuaian tempat prakerin dengan kompetensi siswa akan menjadi faktor pendukung apabila tempat pelaksanaan dan bidang pekerjaan siswa saat prakerin sesuai dengan kompetensi keahliannya. Siswa tidak mengalami hambatan jika tempat pelaksanaan dan bidang pekerjaannya sesuai dengan kompetensi keahliannya.

Di samping itu belum adanya keterlibatan DU/DI dalam penyusunan kuri- kulum, padahal DU/DI lebih mengetahui kebutuhan dan kriteria kerja di industri. Merujuk pada Depdikbud (1997), bahwa pengembangan kurikulum PSG bertujuan untuk meningkatkan kebermaknaan substansi kurikulum yang akan dipelajari di sekolah dan di industri sebagai satu kesatuan utuh dan saling melengkapi, serta pengaturan kegiatan belajar mengajar yang dapat dijadikan acuan bagi para pengelola dan pelaku pendidikan di lapangan, sehingga pada gilirannya peserta didik dapat menguasai kompetensi yang relevan dan sesuai dengan yang dipersyaratkan oleh dunia kerja. Pekerjaan yang dikerjakan dan keahlian siswa harus relevan dengan keahlian teknik mesin sehingga tujuan prakerin menjadi tercapai.

Faktor kedisiplinan siswa tidak menunjukkan ada hambatan baik di industri kecil, menengah maupun besar. Temuan ini betentangan dengan hasil wawancara dengan siswa dan instruktur bahwa terdapat siswa yang membolos dan sering datang terlambat. Hal ini disebabkan dari faktor individu siswa sendiri. Oleh karena itu untuk mengatasi kurangnya kedisiplinan peserta didik, sekolah seharusnya melakukan koordinasi dengan DU/DI dengan memberikan motivasi agar tidak mengulangi kesalahan (Mahmudi, 2013).

Bimbingan dan monitor menunjukkan bahwa tidak ada hambatan baik dari sumber data siswa, guru dan instruktur prakerin. Akan tetapi dalam pelaksanaan prakerin siswa memerlukan bimbingan dari instruktur prakerin yang intensiv dan siswa harus aktiv karena siswa yang mendapat bimbingan intensif dari guru pamong mempunyai kompetensi yang lebih baik daripada siswa yang mendapat bimbingan tidak intensif (Efendi, dkk., 2012). Guru melakukan monitoring minimal tiga kali selama masa PSG, sedangkan pembimbing dari industri setiap hari memberikan pembimbingan kepada peserta didik, namun karena kesibukan mereka terhadap pekerjaan utamanya se- 
hingga bimbingan dengan peserta didik PSG menjadi kurang (Mahmudi, 2013). Sedangan hasil penelitian ini guru melakukan monitoring minimal dua kali. Guru cenderung menyerahkan bimbingan dan monitoring pada instruktur. Instruktur mempunyai tugas utama dari perusahaan sehingga proses bimbingan dan monitoring prakerin kurang maksimal disamping itu siswa kurang aktiv dalam konsultasi dengan instruktur.

Di samping itu hasil penelitian menunjukkan bahwa hambatan dan faktor penyebabnya prakerin ditinjau dari evaluasi siswa SMK Teknik Pemesinan yang di Industri kecil, menengah, dan besar dari sumber data siswa, guru dan instruktur secara umum tidak ada hambatan. Pada evaluasi prakerin, tidak ada hambatan disebabkan oleh tidak adanya ujian atau evaluasi akhir yang dilakukan sekolah dan DU/DI dari jurnal harian yang dibuat siswa dan laporan dari industri untuk menentukan hasil prakerin. Padahal jurnal harian digunakan untuk memantau kerja siswa dan referensi penyusunan laporan prakerin. Hal ini relevan dengan penelitian Suwarman (2014) yang menyatakan bahwa buku jurnal yang telah diisi dengan lengkap oleh siswa akan memudahkan siswa untuk menyusun laporan pelaksanaan prakerin. Buku jurnal digunakan sebagai acuan untuk crosscheck pekerjaan siswa dengan kompetensi keahliannya. Selanjutnya Sutrisno (1997) menambahkan dalam penelitiannya bahwa untuk mengetahui sejauh mana materi pelatihan telah dikuasai oleh siswa, perlu diadakan ujian, baik teori maupun praktek. Hal ini tidak sesuai dengan hasil temuan wawancara dengan instruktur yang menyatakan bahwa tidak semua industri melakukan ujian. Seharusnya ujian akhir prakerin dilakukan untuk mengetahui hasil/prestasi prakerin siswa.

Hasil penelitian yang terkait dengan refleksi dan tindak lanjut prakerin tidak ditemukan hambatan baik menurut siswa, guru, maupun instruktur. Temuan hasil pengisian kuesioner dan wawancara siswa mengalami kesulitan dalam merencanakan pekerjaan/usaha yang dilakukan setelah lulus sekolah dan siswa belum yakin bahwa pekerjaan ditempat prakerin menunjang karirnya. Hal ini tidak relevan dengan tujuan prakerin yang mempersiapkan siswa untuk siap kerjaatau akan menjadi wirausaha. Hal ini didukung penelitian Ramadani (2015) Prestasi prakerin siswa berkontribusi secara langsung terhadap minat berwirausaha, karena tinggi rendahnya prestasi prakerin siswa memberikan pengaruh terhadap perubahan minat berwirausaha siswa. Demikian pula hasil penelitian Nidhom (2013) menyatakan ada hubungan yang signifikan antara kesesuaian tempat prakerin dengan hasil prakerin peserta didik kompetensi keahlian TKJ di SMK kota batu, kesesuaian tempat prakerin memberikan hasil positif terhadap hasil prakerin.

\section{SIMPULAN DAN SARAN}

Secara umum hambatan dan faktor penyebabnya dalam pelaksanaan prakerin siswa dapat diperikan berikut. Pertama, hambatan di industri kecil (menurut siswa, guru, dan instruktur) paling tinggi pada tahap pelaksanaan, yaitu yang terkait dengan: (1) fasilitas praktik bagi siswa, dan fasilitas di industri tidak lengkap, faktor penyebabnya industri kecil dimiliki oleh perseorangan dengan modal, sarana dan prasarana terbatas; dan (2) saat prakerin terdapat siswa yang memperoleh pekerjaan dan tugas yang tidak relevan dengan keahliannya, penyebabnya pekerjaan siswa terkadang mengikuti pekerjaan industri yang bukan merupakan bidangnya; kurangnya komunikasi antara guru dengan instruktur prakerin khususnya terkait kesesuaian keahlian/kompetensi serta pihak DU/DI belum dilibatkan dalam pembuatan kurikulum khususnya program prakerin. 
Kedua, hambatan di industri menengah (menurut siswa, guru dan istruktur) yang paling tinggi terdapat pada tahap pelaksanaan, yaitu kompetensi yang diterima siswa, pada saat prakerin terdapat siswa yang memperoleh pekerjakan dan tugas yang tidak relevan dengan keahliannya, penyebabnya: (1) sarana dan prasarana (mesin) di industri tidak sama dengan yang ada disekolah, (2) kurangnya komunikasi antara guru pembimbing dengan instruktur prakerin khususnya terkait kesesuaian kompetensi, dan (3) belum dilibatkannya pihak DU/DI dalam pembuatan kurikulum khususnya program prakerin. Sedangkan hambatan menurut guru dan instruktur terdapat pada tahap persiapan, yaitu perencanaan akomodasi dimana disebabkan oleh pihak sekolah dan DU/DI tidak menyediakan akomodasi yang mencakup tempat tinggal sementara (kos) dan kendaraan.

Ketiga, hambatan di industri besar (menurut siswa, guru, dan instruktur) paling tinggi terdapat pada tahap pelaksanaan, yaitu kompetensi yang diterima siswa, pada saat prakerin terdapat siswa yang memperoleh pekerjakan dan tugas yang tidak relevan dengan keahliannya, penyebabnya: (1) sarana dan prasarana (mesin) di industri tidak sama dengan yang ada disekolah, (2) kurangnya komunikasi antara guru pembimbing dengan instruktur prakerin khususnya terkait kesesuaian kompetensi, dan (3) belum dilibatkannya pihak DU/DIdalam pembuatan kurikulum khususnya program prakerin. Sedangkan hambatan menurut guru dan instruktur terdapat pada tahap persiapan, yaitu perencanaan akomodasi dimana disebabkan oleh pihak sekolah dan DU/ DI tidak menyediakan akomodasi yang mencakup tempat tinggal sementara (kos) dan kendaraan.

Pertama, sekolah disarankan: (1) membuat surat kesepakatan/MoU dengan pihak DU/DI dengan tujuan saling menguntungkan dan tidak ada yang dirugi- kan; (2) membuat pusat informasi dan bimbingan prakerin agar siswa melaksanakan prakerin di industri yang relevan dengan bakat, minat, dan kompetensi keahliannya/kompetensinya; (3) lebih memperhatikan dan membantu mencarikan tempat tinggal sementara (kos) yang nyaman dan kondusif baik dari lingkungan, kesehatan, keamanan dan akses transportasi menuju tempat prakerin; (4) melibatkan pihak DU/DI dalam penentuan kurikulum agar teori dan praktek di sekolah relevan dengan praktek di DU/DI, sehingga pihak industri dapat memberi pekerjaan dan tugas kepada siswa sesuai dengan keahlian dan kompetensi; (5) memberikan pembekalan dengan menambahkan muatan sikap disiplin dan menanamkan konsep kepada siswa bahwa prakerin tidak sekedar syarat kelulusan sekolah; dan (6) meningkatkan intensitasnya untuk melakukan pembimbingan;

Kedua, industri disarankan: (1) memasukkan program prakerin ke dalam sasaran mutu dan instruksi kerja ISO DU/ DI, di mana hal ini akan mendapatkan evaluasi secara periodik dan akan dinilai oleh lembaga sertifikasi; (2) menggalakkan K3 pada siswa prakerin dimana K3 merupakan aspek penting dalam aktifitas bekerja, agar kecelakaan kerja dapat dicegah; (3) bekerjasama dengan pihak sekolah dalam membimbing kedisiplinan siswa prakerin agar pada saat siswa lulus menjadi bagian industri yang memiliki kriteria disiplin dan etos kerja tinggi; dan (4) melakukan evaluasi/ujian pada siswa diakhir prakerin yang sudah mereka laksanakan, sehingga siswa tidak berfikiran sekedar mengikuti prakerin.

Ketiga pemerintah disarankan: (1) bersinergi dalam merumuskan kebijakan hubungan prakerin dengan ketenagakerjaan, baik itu melalui Dinas Pendidikan, Dinas tenaga kerja,maupun dinas terkait lainnya; dan (2) memberikan reward kepada pihak DU/DI baik berupa keringanan pajak, kemudahan akses pemasaran, 
maupun jenis lainnya, atas partisipasinya dalam membangun dunia pendidikan kejuruan yang dalam hal iniadalahprogram prakerin.

\section{DAFTAR RUJUKAN}

Anwar. 2002. Pelaksanaan Program Pendidikan Sistem Ganda pada SMK di Kota Kendari. Jurnal Pendidikan dan Kebudayaan, 8(36): 418--435.

Apriyadi, C. \& Sulistyo, B. 2012. Pelaksanaan Praktik Kerja Industri (Prakerin) pada Jurusan Teknik Sepeda Motor SMKN 2 Pengasih. Jurnal Pendidikan Teknik Otomotif, 16(1): 26--38, (Online), (http://eprints. uny.ac.id/id/eprint/43189, diakses 23 Desember 2016).

Badan Pusat Statistik (BPS).2015. Tingkat Pengangguran SMK yang Paling Besar. (Online), (https://www.bps. go.id/subjek/view/id/9, diakses 23 Juli 2015).

Departemen Pendidikan dan Kebudayaan 1997. (Online), (https://www.Google.co.id/search?q=Departemen+ Pendidikan+dan+Kebudayaan+1997 .....=chrome \&ie $=$ UTF-8, diakses 23 Juli 2015).

Efendi, S., Sutadji, E. \& Mukhadis, A. 2012. Pencapaian Kompetensi Prakerin Ditinjau dari Persepsi Siswa tentang Kualifikasi Tempat, Pembimbingan, dan Umpan Balik pada Keahlian Teknik Mesin SMK. Jurnal Teknologi dan kejuruan, 35(2): 115--124

Ekawati, D.A. 2012. Hubungan Kerja Sekolah dengan DU/DI (Studi Situs SMK Negeri Donorojo Kabupaten Pacitan). Tesis tidak diterbitkan. Surakarta: Universitas Muhammadiyah Surakarta.

Indaryanto, N. 2011. Analisis Pelaksanaan Prakerin dalam Rangka Peningkatkan Kemampuan Siswa pada Kurikulum Kelompok Produktif (Studi
Kasus di Program Keahlian Teknik Bangunan SMKN 5 Surakarta). Skripsi, Tidak Diterbitkan. Surakarta: Universitas Negeri Sebelas Maret.

Jatmoko, D. 2013. Relevansi Kurikulum SMK Kompetensi Keahlian Teknik Kendaraan Ringan terhadap Kebutuhan Dunia Industri di Kabupaten Sleman. Tesis tidak terbitkan. Yogyakarta: Pascasarjana UNY Yogyakarta.

Jefriando, M. 2015. Pengangguran Terbanyak Lulusan SMK-Detik finance 05/05/2015. (Online), (http://finance.detik.com/read/2015/05/05/1453 20/2906162/4/bps-pengangguranterbanyak-lulusan-smk, diakses 12 April 2016).

Karyono, A. 2009. Kontribusi Status Industri Tempat Prakerin, Lama Prakerin, dan Motivasi Belajar terhadap Sikap Kewirausahaan Siswa SMK di Kabupaten Indramayu. Jurnal Teknologi dan Kejuruan, 32(2): 165-176).

Mahmudi, M. 2013. Pelaksanaan Pendidikan Sistem Ganda Bersertifikat ISO di SMK Negeri 1 Malang. Jurnal Kebijakan dan Pengembangan Pendidikan, 1(2): 26--38.

Molikavia, R. 2015. Hubungan Kecakapan Sosial dan Kemampuan Logika dengan Keberhasilan dalam Prakerin Siswa SMK. Jurnal Teknologi dan Kejuruan, 38(1): 15--24.

Mukhadis, A. 2016. Metodologi Penelitian Kuantitatif: Contoh Aplikasinya dalam Bidang Pendidikan. Malang: Aditya Media Publishing.

Mulyani, M.A. 2011. Peran Guru Pembimbing dalam Kesiapan Kerja Siswa SMK Negeri 2 Sawahlunto Sumatera Barat. Tesis tidak diterbitkan. Sumatera: PPs Universitas Sumatera

Nayono, E.S. 2012. Kerjasama Internasional Perguruan Tinggi: Peng- 
alaman di Universitas Negeri Yogyakarta. Makalah Disajikan dalam Workshop Inisiasi Kerjasama dengan Perguruan Tinggi Asing Institut Seni Indonesia Yogyakarta, Yogyakarta, 13 Desember 2012.

Nidhom, A.M. 2013. Hubungan Kesiapan Belajar, Lama Prakerin, Kesuaian Tempat dan Partisipasi DUDI dengan Hasil Prakerin Peserta Didik Kompetensi Keahlian TKJ di SMK Kota Batu. Tesis tidak diterbitkan. Malang: PPs Universitas Negeri Malang.

Peraturan Pemerintah Pendidikan dan Kebudayan Republik Indonesia No. 29 Tahun 1990. Tentang Pendidikan Menengah, Presiden Republik Indonesia.

Perwitasari, D.F. 2013. Hubungan Fasilitas Praktikum TKJ di Sekolah, Kesesuaian. Tempat Prakerin, dan Kompetensi TKJ Siswa dengan Hasil Uji Kompetensi Keahlian. Jurnal Pendidikan Sains, 1(4): 425--431.

Prasetyo, B. 2013. Evaluasi Pelaksanaan Praktik Kerja Industri Kompetensi Keahlian Teknik Gambar Bangunan SMK N 2 Klaten. Jurnal Pendidikan Vokasi, 3(1): 78--91.

Ramadhani, A.H. 2015. Kontribusi Pengetahuan Kewirausahaan, Prestasi Prakerin dan Kompetensi Keahlian, terhadap Minat Berwirausaha serta Dampaknya pada Kesiapan Berwirausaha Siswa SMK Paket Keahlian Teknik Pemesinan Madura. Tesis tidak diterbitkan. Malang: PPs Universitas Negeri Malang,
Riza, F.M. 2013. Analisis Faktor Penghambat Pelaksanaan Praktek Industri pada Mahasiswa S1 Pendidikan Teknik Mesin, Lembaga Pendidikan Universitas Negeri Malang, dan Industri. Skripsi tidak diterbitkan. Malang: Universitas Negeri Malang.

Susanti, A.I. 2015. Kontribusi Persepsi Siswa tentang Kualitas Guru, Kesesuaian, dan Hasil Prakerin terhadap Pemployability Skills Siswa SMK. Jurnal Teknologi dan Kejuruan, 38(2): 121--132

Sutrisno, Dardiri, A., \& Sugandi, R.M. 2015. Pelaksanaan Pembelajaran Prakerin Bidang Keahlian Teknik Bangunan Sekolah Menengah Kejuruan. Jurnal Teknologi Kejuruan, 38(1): 51--56.

Suwarman. 2014. Pengelolaan Praktik Kerja Industri pada Program Keahlian Teknik Pemesinan SMK Se-Kabupaten Kulon Progo. Jurnal Pendidikan Vokasi, 4(1): 25--34.

Taufik, I. 2016. Pengaruh Prakerin terhadap Kesiapan Kerja Siswa. Jurnal Pendidikan Vokasional Teknik Mesin, 4(1): 41--50.

Undang-Undang Republik Indonesia, Nomor. 20, Tahun 2003, tentang Sistem Pendidikan Nasional. Jakarta: Depdiknas.

Wahono. 2014. Kualitas Pembelajaran Siswa SMK Ditinjau dari Fasilitas Belajar. Jurnal Ilmiah Guru “COPE”, 01(18): 66--71. 